\title{
Missed Opportunities: Early Attempts to Obtain Bukovynian Orthodox Clergy for the Ukrainian Pioneers of Alberta
}

\author{
Jars Balan \\ Canadian Institute of Ukrainian Studies, University of Alberta
}

\begin{abstract}
Immigration from the Austro-Hungarian crown land of Bukovyna to the Canadian West was initiated in 1897-98, continuing thereafter until the outbreak of the First World War. Comprised mostly of ethnic Ukrainians, but including a small number of Romanians and families of mixed marriages, the peasant farmers from Bukovyna took out homesteads alongside the fledgling colony established northeast of Edmonton a few years earlier by Ukrainians from Galicia. An immediate concern of the settlers was the lack of any priests to serve their pastoral needs and to provide leadership for the communities that they were struggling to establish in challenging circumstances in the New World. Although itinerant priests dispatched by the Russian Orthodox mission based in San Francisco began visiting the Ukrainian settlers in Alberta beginning in July 1897 at the request of Russophiles among the first Galician homesteaders, the new arrivals from Bukovyna found them to be less than satisfactory because of linguistic and cultural differences. Almost immediately, the Bukovynians began appealing to the Orthodox Church in Bukovyna for clergy who could speak the Bukovynian Ukrainian dialect and "Wallachian," so that they would not be dependent on priests from the Russian Mission. Despite numerous requests sent to the Metropolitanate of Bukovyna over the course of the next decade and a half-not only from Alberta, but also from other Bukovynian colonies in Canada-no Ukrainian clergy were ever assigned by church officials in Chernivtsi to serve the Orthodox faithful overseas. Drawing on archival sources, press reports and secondary sources, this article reconstructs these efforts by the pioneer era Ukrainian settlers from Bukovyna to obtain Orthodox clergy from their native land, at the same time suggesting reasons for their failure.
\end{abstract}

Keywords: Orthodox Church, Bukovyna, Ukrainian Pioneers, Canadian immigration.

$\mathrm{U}_{\mathrm{i}}$ krainians began coming to Canada from the Austro-Hungarian Empire in the last decade of the nineteenth century, among them immigrants from the crown land of Bukovyna. Although some individuals and a few families migrated overseas as early as the 1870s, groups of Bukovynian settlers only started leaving for the Canadian West in 1896-97.1 Thus, by

1 For details on the inauguration of Bukovynian emigration to Canada, see Botushans'kyi, "Pochatky" 77-80. A more comprehensive overview of emigration 
the fall of 1898 over a hundred families from fifteen villages in Kitsman and Chernivtsi counties had settled roughly ninety kilometers northeast of Edmonton along the eastern edge of what was known as the Beaver Creek, Star-Wostok, or Limestone Lake colony, founded by Ukrainians from Galicia in 1894. Meanwhile, other Bukovynian immigrants created similar settlements in parts of Manitoba and Saskatchewan.

An almost immediate concern of the new Bukovynian arrivals to Alberta was re-establishing the religious life they had known in their native land, where the Orthodox Church played a central role in the everyday lives of Ukrainian peasant farmers. Because the ritual observances attached to births, deaths, baptisms, and weddings all required that a priest administer the sacraments according to the customs and practices of the Eastern Church, it was important to the newcomers that clergy familiar with these rites be available to officiate at such important occasions.

Included among the Galicians who first homesteaded the Star-Wostok area were some thirty Russophile families determined to abandon the Greek Catholic Church in favour of Russian Orthodoxy. Even though the Galician Russophiles and their fellow "Ruthenians" from Bukovyna had a common interest in founding an Orthodox Church in Alberta, the two groups pursued this objective in different ways owing to their dissimilar backgrounds. Whereas Russophile Galicians considered themselves to be "returning" to their ancestral Orthodox faith, Bukovynians were simply interested in maintaining ties to their mother church in Chernivtsi.

The first Ukrainian priest to visit Alberta was Fr. Nestor Dmytriv (Dmytrow, Dmytriw) of the Ruthenian Greek Catholic Church, who toured pioneer Ukrainian colonies in Western Canada in April and May 1897 on a fact-finding mission for the Canadian Department of the Interior. In addition to investigating the progress his countrymen from AustriaHungary were making, everywhere that Fr. Dmytriv went he held religious services and tended to the immigrants' pastoral needs while initiating the organization of congregations dedicated to constructing churches. Not only Greek Catholic Galicians but also Orthodox Bukovynians welcomed Fr. Dmytriv's visit to their fledgling communities, for the settlers sorely missed having spiritual leadership and care at a particularly trying time in their new lives. They especially appreciated having a priest who spoke their language and was familiar with their ancestral forms of worship, unlike the French Roman Catholic or English Protestants clerics they encountered in

from Bukovyna can also be obtained in Botushans'kyi and Chaika. Although hard figures are difficult to derive from available records, it is believed that roughly twenty percent of the first wave of Ukrainian immigrants to Canada from the Habsburg Empire came from Bukovyna, and eighty percent from Galicia. 
the Canadian West. Consequently, wherever Dmytriv went Bukovynians also attended his services, which, of course, did not differ fundamentally from those in the Orthodox Church. Contributing to the warm reception Dmytriv received was the fact that many Ukrainians in Bukovyna did not harbour negative feelings toward the Greek Catholic Church, since the small number of Greek Catholic parishes in northern Bukovyna (comprised mostly of Galicians who had moved to the crown land) coexisted peacefully with the Orthodox majority and were not threatening to the denominational status quo. ${ }^{2}$

Several months before Fr. Dmytriv's groundbreaking trip to Canada, Russophile Galicians in Alberta had already approached the Russian Orthodox Mission in San Francisco with a request for pastoral support (Pravoslavnyi amerikanskii vestnik 212-13). In response, Nicholas (Ziorov), the bishop of the Holy Synod's Eparchy of the Aleutian Islands and Alaska, dispatched two Russian clerics from Seattle to the pioneer Ukrainian settlements outside Edmonton shortly after Dmytriv's visit. On 18 July 1897 the delegated missionaries, Fr. Dmitrii Kamnev (Kamneff) and Deacon Vladimir Aleksandrov (Alexandrof, Alexandroff), celebrated the first Orthodox liturgy on Canadian soil at Wostok, Alberta, drawing a large crowd of local colonists, including a handful of Bukovynians. ${ }^{3}$ The visit

2 For instance, Fr. Panteleimon Bozhyk (Bozyk), a native of the Bukovynian village of Onut and an immigrant to Alberta, offered the following observation while explaining why he left the Russian Orthodox Mission to join the Greek Catholic Church in Canada in 1923: "In Zastavna county, from whence I came, there was not the slightest bit of antipathy toward the Greek Catholic Church. People knew about Greco-Catholicism in our area because of the fact that there were Greek Catholic congregations in [the village] of Pohorilivka and in Zastavna, and also because in Galicia, a short distance across the Dnister [River], there [mostly] lived Greek Catholics, to whom Bukovynians often went for various needs" (Chomu ia navernuvsia 11-12).

3 When Kamenev in his report, "Pravoslavie v Kanadi" (Amerikanskii pravoslavnyi vestnik 26-29; formerly Pravoslavnyi amerikanskii vestnik), claimed that six hundred souls had been converted to Orthodoxy in the Beaver Creek colony, Fr. Dmytriv responded that the boast was greatly exaggerated given that there were not even that many immigrants homesteading in the area by July 1897. Speaking from firsthand knowledge, Dmytriv described in detail the Limestone Lake settlement and asserted that at the time the total population of the colony consisted of some 120 families, 27 of whom were Orthodox Bukovynians, while the remainder were Greek Catholics with the exception of a handful of families who were Roman Catholic Ruthenians. Nonetheless, Kamnev's account stated that, after the liturgy, leaders of the fledgling community wrote a petition to Bishop Nicholas asking to be admitted to the Russian Orthodox Church, and that a committee was formed to initiate the construction of a church and a rectory at Wostok. Among the ten committee 
marked the beginning of a determined struggle between Russian Orthodox and Ruthenian Greek Catholic missionaries keen on winning or keeping adherents among the recent Ukrainian immigrants.

Fr. Dmytriv then made a follow-up trip to the Canadian Prairies in the autumn of the same year, when he once again spent time in the Beaver Creek colony in an effort to counter the inroads that had been made by the Russian Orthodox mission in July. ${ }^{4}$ The Austro-Hungarian consul to Canada, Eduard Schultze, a resident of Montreal, discussed his activities in a 15 October 1897 letter to the Ministry of Foreign Affairs in Vienna. ${ }^{5}$ In his report Schultze noted that Fr. Dmytriv was serving the Greek Catholic settlers from Galicia, while "Orthodox villagers from Bukovyna were remaining without pastoral care because the Orthodox ordinariate in Chernivtsi had not sent a single one of its missionaries here" (Botushans'kyi, “My-brattia zamors'ki'” 102). This, Schultze went on to point out, had provided an opportunity for Russian Orthodox authorities in San Francisco to assert their spiritual leadership over the Orthodox Bukovynians-a matter that should have been of concern to the AustroHungarian government given the longstanding tsarist campaign to undermine Vienna's control over the Slavic territories in the eastern parts of the Habsburg Empire. Even though these developments were taking place halfway around the world, the defection of Ruthenian immigrants to the Russian Orthodox Church (as was already occurring in the United States) could have negative consequences for maintaining the loyalty of their compatriots still in Europe.

In May 1898 the two Russian clerics from Seattle also paid a second visit to the Canadian Northwest, spending almost a month in the burgeoning Ukrainian settlements northeast and south of Edmonton. By then Greek Catholic officials in Galicia had assigned Fr. Pavlo Tymkevych

members were two settlers who had recently arrived from Bukovyna-Dmytro Balan and Ivan Tkachuk—both of whom landed in Quebec in May 1897.

${ }^{4}$ During his fall 1897 tours of Ukrainian pioneer colonies in the Canadian West, Fr. Dmytriv again ministered to Bukovynian settlers on several occasions. For instance, in the Stuartburn area of Manitoba he consecrated two parcels of land for cemeteries, one for Greek Catholics and the other for Orthodox settlers. He also encountered Bukovynian immigrants while touring Saskatchewan later the same month. See Panchuk, Bukowinian Settlements 9-10; St. Michael's Ukrainian Greek Orthodox Church 2-3.

5 In 1895 Schultze wrote a letter introducing the agronomist Dr. Yosyf Oleskiv (Josef Oleskow, Oleskiw) to Canada's minister of the interior, and Oleskiv in turn had recommended that the minister hire Fr. Dmytriv to study the situation in the Ukrainian colonies on the Prairies. See Kaye 391-92. 
(Paul Tymkiewicz, Tymkievytch, Tymkieweitch) to work in Alberta, where he resided until the autumn of 1898 in what proved to be only a partially successful attempt to curb the Russophile activists' influence among the Galicians.

Immediately after the departure of Kamnev and Aleksandrov, a group of settlers in the Limestone Lake area took it upon themselves to send a request to the Holy Synod in St. Petersburg to provide a permanent priest for them (cf. Galician settlers, reel 321). Of the letter's twenty-five signatories, only one, Ivan Tkachuk, was a native of Bukovyna; the remainder were Galician Russophiles mobilized behind the leadership of Teodor Nemyrs'kyi (Theodore Nemirsky). ${ }^{6}$

However, at the same time the Bukovynians in the colony also began making efforts to get the metropolitan of Chernivtsi to send priests from his jurisdiction to serve in Canada. As indicated in a petition sent on 21 September 1898 to Metropolitan Arkadii (Chuperkovych), Orthodox metropolitan of Bukovyna from 1896 to 1902, the Bukovynians had difficulties understanding the Russian-speaking missionaries who had been sent to them from the United States, and greatly preferred having someone come from their native land to satisfy their religious needs:

Your Grace!

Signed below are Gr[eco] Or[ientale] (Orthodox) Bukovynian immigrants to American Canada comprising 115 families, settled in one specific area, distinct from 30 families from Galicia, who also want to convert to Orthodoxy; all [of us] graciously request that as soon as possible a priest [be sent to us] who knows the Little Russian [Ukrainian] and Bukovynian languages, because we ourselves are conducting funerals in this place, [and] some children are sitting here unbaptized for several months; for whenever there comes a priest who [only] speaks the Great Russian language, our people do not understand him well-especially during Holy Confession.?

Although the letter was written by Stefan Gudzovatyi, ${ }^{8}$ its return address was given as "Amerika Canada Alberta / Dmytro Balan farmer / in

\footnotetext{
${ }^{6}$ Many of the signatories, including Tkachuk, appear to have been illiterate, judging from the large number of farmers who signed with an "x."

7 My trans. This handwritten letter in Ukrainian is photo-reproduced along with a typeset text in Sych, $Z$ "Novoho kraiu" 17-18, 49-50. The research report is also available in a separate 1991 edition published in Chernivtsi under the same title by "Redaktsiino-vydavnychyi viddil Chernivets'koho oblpolihrafvydavu." The original of the document is housed along with other records of the Metropolitanate of Bukovyna in the State Archive of Chernivtsi Oblast in Chernivtsi.
}

8 Gudzovatyi (Gudzowaty, Gudzowatye, Gudzowatyj, Hudzovaty, Gudzuwaty, b. 1851 
Bivur-Krik / Post. Edna-Alta, / Bivur-Krik."9 Gudzovatyi, using AustroGerman spellings of place names, signed the letter on behalf of nineteen heads of immigrant families from villages across northern Bukovyna, including: Unter-Scheroutz, Kysyliw, Czornowka, Rarancze, Boian, Molodiea, Kotul-Bainsky, Lukowitz, Toporoutz, Rohozna, Ober-Scheroutz, Czahor, Zadubrowka and Boriwtzi. This was to be the first of many such entreaties made to the Orthodox Church in Bukovyna to send priests to minister to their compatriots in Canada.

Coincidentally, this appeal from Alberta was almost simultaneously reinforced in a letter to the Chernivtsi newspaper Bukovyna, ${ }^{10}$ published on 28 September 1898 by none other than Fr. Dmytriv. By then Dmytriv had returned to the United States, where he was to subsequently make his permanent home despite originally planning to relocate to Canada. After debunking several popular myths about emigration and conditions in Canada, the Greek Catholic cleric strongly urged the Orthodox eparchy in Chernivtsi to supply priests to the Bukovynians who were settling in evergreater numbers in the Canadian West:

Our people-especially from Bukovyna-are terribly ignorant; having listened at home and en route to the fables of dishonest agents, upon arrival here, and for obvious reasons, they became disillusioned. They discovered the reality here. They found 113 morgs of fields without all of the wonderful things the agents had promised them at home and along the way. Those who were more circumspect chose good land, [while] those who were ignorantand also lacking in means-settled on wasteland, because it is impossible to find a country in this world where all of the land is of top quality. Our poor peasant [muzhyk], fed on potatoes, cannot become an American worker, [and] for that reason our people were unable to get work on the railway in the Crow's Nest alongside workers from other nations. Our man pined for his church, for his priest, for his familiar routines, and that is the source of the

in Raranche, Bukovyna, d. 1 September 1931 in Vegreville, Alberta) came to Canada aboard the SS Pisa without a family. Landing at Halifax on 28 May 1898, he filed for a homestead at NE 30-57-15 W4 (north of the future hamlet of Whitford) on 15 April 1899.

9 Dmytro (Demytyr, Dmetro) Balan (b. 1859 in Raranche, Bukovyna) came to Canada aboard the SS Arabia on 26 May 1897 with his wife Pavlina (possibly Katrina, b. 1860 also in Raranche) and three children: Mariia (aged nine), Veronika (four), and Sanda (one). He filed for a homestead south of present-day Andrew at NE 16-56-17 W4 (in what became the Suchava district) on 11 June 1897.

10 Bukovyna was the leading Ukrainian newspaper in the eponymous AustroHungarian crown land from 1885 to 1918, and the unofficial organ of the Ukrainian Populists in Bukovyna. 
complaints, laments, and letters [sent] to the old country, to family members, and even to those authorities who were precisely responsible for driving him overseas. Anyone who knows the kind of power that one's own land exerts on a peasant will not be surprised by the kind of yearning that grips an ordinary person's heart for his ancestral land. In other nations this is completely lacking. An Englishman, Frenchman, or German is utterly unsentimental-he knows that if fate has tossed you overseas, if it has placed you here, then you have to stand here and, gritting your teeth, forge your destiny. I know an English engineer, who for 18 years has been working on a farm 60 miles from the city-today he is wealthy man-but to be able to survive that entire time, what terrible strength and endurance were required to live through it all. But none of our intellectuals would be able to achieve this, much less our peasant, bound to his native land, his river, his church, and his tavern. I will just make one more observation in concluding, [namely,] that our people from Bukovyna, such as they are, are not ready to be sent into the world. It will take fifty years of work on them, and then they will be prepared to become American farmers. And since they are already in Canada, then the Orthodox eparchy should send at least one priest after them so that the agents of Russian Orthodoxy do not settle among our poor people. And since people, unavoidably, have to emigrate, let guardians take good care of our people so that neither at home, nor along the way, no one fleeces them, so that no one tells them fables about the promised paradise, and if they, knowing the truth, come to Canada with sufficient capital and intelligence, then they will never have any regrets, just as those who brought capital and intelligence with them from Galicia and the United States also have no regrets. ${ }^{11}$

A member of the secular clergy and a strong supporter of the Ukrainian national populist movement, Fr. Dmytriv clearly was not interested in taking advantage of the vulnerable situation of the Ukrainian immigrants from Bukovyna in order to recruit them to join the Greek Catholic Church. He was instead motivated by a desire to prevent them from falling into the clutches of the Russian Orthodox Mission, which was also making inroads among disenchanted Greek Catholic Galicians.

It took more than a half a year for the Consistory of the Bukovynian Orthodox Church to reply to the Beaver Creek settlers. In his letter of 5 April 1899, the consistory administrator, writing on behalf of Metropolitan Arkadii, stated unambiguously:

We send you our archiepiscopal blessings far beyond the sea and regret that we cannot satisfy your request, namely, to send you a priest from our

11 Reproduced in Sych, $Z$ "Novoho kraiu" 16-17. My trans. Notwithstanding the concern that Fr. Dmytriv showed for Bukovynians, in his writings he repeatedly described them (not without some justification) as unenlightened and backward. 
archeparchy, owing to the fact that the Orthodox Religious Fund is dedicated solely to Bukovyna and we do not hold other funds with which we could support Orthodox priests for Canada. (Botushans'kyi, "My-brattia zamors'ki'”'103)

To emphasize that the church authorities in Chernivtsi felt no particular responsibility for helping Bukovynians who had gone abroad, the administrator stated: "having separated from our fatherland, you at the same time forfeited sharing in its blessings derived from the Bukovynian religious fund" (Botushans'kyi 103).12

Meanwhile, a third Russian Orthodox mission was undertaken to Alberta in the late spring of 1899, followed by a fourth in May 1900. By then the representatives of the Russian church had a more nuanced understanding of the situation in the Beaver Creek colony and the San Francisco Eparchy realized the advantages of sending priests who were fluent in Ukrainian and knowledgeable about the differences among the various Ruthenian immigrants from the Habsburg Empire. ${ }^{13}$ Undoubtedly taking into account what had been learned from the visits by the itinerant missionaries from Seattle, when Bishop Tikhon (Bellavin, who had assumed leadership over the Russian Orthodox Mission in September 1898) posted the first resident Orthodox priest to Alberta in 1900, he wisely chose an ethnic Ukrainian, Father Yakiv Korchyns'kyi (Yakov or Jacob [James] Korchinsky, Korchinskii, 1861-1941), for this task at a critical juncture in the evolution of the Russian Orthodox Church in Canada.

Fr. Korchyns'kyi arrived in Edmonton accompanied by his wife and a precentor, Ivan Soroka, in late November $1900 .{ }^{14}$ Although some details

12 As Botushans'kyi notes, although the letter from Beaver Creek made no request for material support from Chernivtsi, the Orthodox Religious Fund under Vienna's control was well endowed and could certainly afford to subsidize a few priests in Canada. The Orthodox Church was also not lacking in other resources, for it owned a quarter of the landholdings in Bukovyna and could easily underwrite the salaries of a few priests sent overseas.

13 For example, in an account of the 1899 Russian Orthodox Mission to Alberta, it was claimed that Bukovynians had "firmer convictions and love than [the Galicians] in regard to the Orthodox religion: for instance, if a Bukovynian has a newborn, he would never take it for baptism to any priest except an Orthodox one, whereas the Galicians have more than a few whose faith is not difficult to shake" (Kamnev and Aleksandrov 441). While not necessarily true in the literal sense (see Ivan Soroka's letter translated below), the observation does suggest an interesting distinction between the often-changeable attitudes of some Galician Russophile converts and those of "cradle-born" Orthodox Bukovynians.

14 Ivan Soroka was born in 1880 in the Podlachian town of Semiatychi (now Semiatycze, a county town in eastern Poland), Belsk (now Bielsk Podlaski) county, 
about Korchyns'kyi's life and background have yet to be determined (cf. Namee; Protopopov), it seems likely that he was originally from Bessarabia or Podillia as he not only knew Russian but wrote and spoke Ukrainian, in addition to being conversant in Romanian. A gifted organizer who had served in Alaska before coming to Alberta, Fr. Korchyns'kyi was the priest who was primarily responsible for successfully laying the groundwork for the long-term development of the Russian Orthodox Church in Canada. During his time in Alberta, a Russian Orthodox congregation was organized in Edmonton and the Russian Orthodox Mission hired a local legal firm to formally register the church with the Government of Canada.

Given the Russian Orthodox Mission's initiative in providing clergy for Canada, it is interesting that the precentor Ivan Soroka, working alongside Fr. Korchyns'kyi, made the next appeal from Alberta for Bukovynian priests. Soroka's letter was published in Pravoslavnaia Bukovina on 21 June 1901.15

Praiseworthy Editors!

I ask the editors to place a few words in your respected newspaper for the benefit our Bukovynian Russian Orthodox nation.

A great many Bukovynians are abandoning their native land, and even their fine landholdings, and are going far overseas to Canada.

In Canada Bukovynians are settling for the most part in the province of Alberta, some of them are remaining along the way in Assiniboia, [and] others in Saskatchewan.

In the province of Alberta there can be found at the present time up to 800 families of Bukovynians, or up to three thousand souls....

Grodno (Hrodna) province. After completing elementary school there in 1895, he undertook a novitiate at St. Anthony Monastery in Lublin province and served as a precentor in the house chapel of the Orthodox bishop of Lublin. In 1898 he was appointed an assistant at the Russian Orthodox episcopal residence in San Francisco and worked there until his reassignment to Canada some two years later. He arrived in Edmonton at the age of twenty on 25 November 1900 in the company of Fr. Korchyns'kyi and the latter's wife, Varvara. During the week the three of them spent waiting for a wagon to take them to Wostok, they visited a dozen Orthodox families in the Rabbit Hill district southwest of Edmonton. After moving to Wostok, Soroka and the Korchyns'kyis lived for a time with Teodor Nemyrs'kyi before relocating to the rectory upon its completion in February 1901. Soroka accompanied Fr. Korchyns'kyi during his missionary travels throughout the areas of Alberta settled by Ukrainian immigrants.

15 Pravoslavnaia Bukovina, a Russophile semi-monthly newspaper dedicated to Orthodox Church affairs, was published in Chernivtsi from 1893 to 1905. It routinely attacked the Western Ukrainian national movement and its leaders while promoting Russophile organizations and praising tsarist policies. 
In the province of Alberta is a place settled by Bukovynians and called "Bukovyna," where an Orthodox church has now been built, and in addition there are five cemeteries in other places, where in the near future churches will be constructed.

In this year almost all of the Bukovynians took Communion with an Orthodox Russian priest, who lives in Wostok-6, 15-20 or 20 miles from the Bukovynians' settlements.

In the previous year, his eminence Tikhon, the Russian Orthodox bishop of the Aleutians and North America, opened a Canadian mission and sent a Ruthenian priest from Ukraine to the province of Alberta, to the place, we call Wostok, where this priest built a home and a church and where 300 Galician Uniate souls united with Christ's Orthodox church.

In this year the day of Christ's Resurrection transpired nicely-up to 800 paskas [paschal breads] were blessed, and only those who did not want to did not eat blessed paska.

Now Orthodox Christians can listen to [church bells] ringing if they go to Wostok for a Divine Liturgy. Father Yakiv Korchyns'kyi travels around to [visit] all of the Bukovynians and celebrates Divine Liturgies, gives Communion, and performs different rites, and he even confesses Wallachians in Wallachian [i.e., Romanian].

It is extremely difficult for one priest to manage, and no one among the Orthodox Bukovynian priests or reverend deacons wants to go and serve their people. Why even in Bukovyna it is unknown that in Canada there are Russian Orthodox churches under the administration of the Russian bishop in the [United] States [residing] in the c[ity] of S[an] Francisco ... and very often Bukovynian priests tell their compatriots that in Canada there will be no one to christen or marry them, or give them Communion. And that greatly demoralizes the Orthodox Bukovynians-upon coming to Canada they completely forget either who they are or that their faith is Orthodox. Frequently they take Communion with Uniate or Polish priests, they have their children christened and married by French[-Canadian Catholic priests], and they live the lives of fornicators until they encounter an Orthodox priest. And they completely neglect to instill the Orthodox faith in their children, [who] often go to Latin[-rite] churches and take Communion there, and their parents do not say anything [about this] to them. One Bukovynian convinced his daughter to work in a Latin[-rite] hospital, and the nuns forced her to go to confession and take Communion with a French[-Canadian] priest, and when an Orthodox [believer] began questioning the girl as to why she had changed her faith, the girl replied: "No one ever taught me my faith, neither a priest nor my parents, whereas I was instructed by [the Catholic] nuns, so afterwards I changed my religion." These are not isolated cases. And all that is because the craving for wealth-the worship of Mammon-dulls their faith.

Oh, if only our compassionate Lord would stir the hearts of the Orthodox pastors of Bukovyna or the hearts of those young people who were preparing to serve God and not Mammon, if [only] any one of them were to 
come here and serve their own people and not allow the Bukovynian Ruthenians' good name to vanish forever!

We firmly believe that such a servant of Christ would not languish in poverty, because the generous people would help him in all of his needs, while the [Russian Orthodox] bishop of North America, it seems to us, would not remain unaware of his labours on behalf of the holy Orthodox Church.

It would be best if a young man with few children, or a widower, or even better a monk, were to come here. There are many such places here where one could have a monastery but for a lack of ascetics.

Whoever would like to know how to come to Canada should write to our Orthodox priest at the following address: Canada, Rev. Father J. Korchyns'kyi [Korchinsky], Alta. Wostok p[ost] o[ffice]. And he [Korchyns'kyi] will write how to travel here and where to turn to.

With respect,

I. Soroka (Sych, Z “Novoho kraiu” 25-26)

The reference to the place called "Bukovyna" in Soroka's letter is to a district east of Wostok, which in 1928 was moved several miles southeast to a location alongside the Canadian Pacific Railway line. In 1900 Bukovynian settlers there began constructing a place of worship for themselves just east of what later became the "new" Wostok, even though the Galicians had already established a cemetery and erected the Holy Trinity Russo-Orthodox Church at "old" Wostok a year earlier. In the meantime the leader of the local Galician Russophiles, Teodor Nemyrs'kyi, had written a letter on behalf of the Bukovynian builders of the church to Bishop Tikhon requesting a loan of two hundred dollars toward the completion of their own church (Nemyrs'kyi, reel 321). These funds appear to have been received, as Tikhon subsequently blessed that sanctuary, dedicated to St. Nicholas, on 9 September 1901 during his first hierarchical visit to Alberta. ${ }^{16}$ Be that as it may, Soroka's letter in Pravoslavnaia Bukovina had no effect on Orthodox Church authorities in Chernivtsi and failed to convince a single Bukovynian priest to move to Canada.

By the time Fr. Korchyns'kyi left Alberta for new pastoral duties in the United States at the end of May 1902, the rapidly expanding Russian Orthodox Mission claimed to be serving almost three thousand faithful in Canada. Approximately two thousand of them were identified as Bukovynian Ukrainians, and another seven hundred were Galician Greek

16 "On Monday his lordship visited the Bukovinian settlement between Wostok and Whitford and there consecrated a new church in the presence of about 300 people, returning to Star that night.... The church in the Bukovinian settlement six miles east of Wostok is named St. Nicholas and has accommodation for a congregation of 400" ("Church Consecration" 5). This article identifies Soroka as "Rev. J. Soroka" and describes him as Fr. Korchyns'kyi's assistant. 
Catholics who had converted to Orthodoxy. Among the faithful were also some forty Romanian families from Bukovyna who had settled north and east of Limestone Lake. Significantly, in a letter Fr. Korchyns'kyi wrote to Bishop Tikhon two months before his departure from Edmonton, he raised the issue of finding someone suitable to replace him in Alberta. He expressed doubts about a single priest being able to provide the necessary pastoral care to the growing Orthodox community in Alberta and therefore suggested that four hieromonks, ${ }^{17}$ ideally from Bukovyna, be assigned to take over the Canadian mission (Korchyns'kyi, reel 361). Korchyns'kyi's pastoral experiences in Alberta had obviously convinced him that it was desirable to have Bukovynian priests minister to their immigrant compatriots in the Canadian West, though he undoubtedly assumed that any such recruits would come under the jurisdiction of the San Francisco see.

Unfortunately, the Russian Orthodox Church never arranged to have a Bukovynian priest brought to Alberta.

It was reported that around 1903 Bukovynian immigrants living in the Shandro district northwest of Willingdon sent a letter to Metropolitan Volodymyr (Repta), who had recently succeeded Metropolitan Arkadii (Chuperkovych). A granddaughter of one of the founders of the Orthodox church in Shandro relates the following:

By the summer of 1903 the church building [which came to be known locally as St. Mary's Church at Shandro] was well advanced. At this time a missionary of another religious faith approached the church board and offered his spiritual services to them. His proposal was declined because they were building a church which was to have a Greek Orthodox minister. The settlers were unanimous in their decision that they would try to get a priest from their native Bukowina.

As a result of this proposal, Nikon Shandro and Stefan Gudzowaty formulated a letter, stating their request to Metropolitan Repta in Chernivtsi. These people wished to practice the same religious faith as they had been accustomed to under Metropolitan Repta's jurisdiction. They advised him that their church was almost completed and they humbly begged him to send a priest.

A few months later Metropolitan Repta acknowledged the receipt of their letter, stating that he was delighted to hear of their building progress. He praised them for their continuous faith in the Orthodox teachings, but was unable at the time to respect their wishes. The province of Bukowina had a severe shortage of priests to service the established parishes. However, he advised them to write to the Russian Orthodox Mission in San

17 A hieromonk is an Orthodox or Eastern Catholic monk who has been ordained to the priesthood or a priest who has received monastic tonsure. 
Francisco where he was certain that the settlers' request would be granted. The Metropolitan assured them the Orthodox faith was the same in all countries and it was irrelevant whether the priest came from Bukowina or San Francisco. (Navalkowsky 28) ${ }^{18}$

So once again, the settlers were denied their request.

This would not be the last time that Bukovynians in Alberta appealed to Chernivtsi to send Orthodox priests. Additional petitions were also made from other parts of Canada in the years before the First World War. But none of them produced the desired result (See also Bozhyk, Tserkov 15; Sych 49-50; Demczuk 231). In the end, the Bukovynian settlers in Alberta were left to their own devices, under the jurisdiction of the Russian Orthodox Church-and were therefore the targets of proselytizing efforts by various dubious sects and by the Canadian Protestant churches that were active among the Ukrainian immigrants.

Interestingly, a 1909 article in the Russophile Orthodox newspaper Svet chided the Bukovynian clergy for their apparent lack of concern for their former parishioners who had emigrated overseas: "A hundred requests forwarded to Bukovina for a priest went unanswered, indicating a preference for the old country benefits and conveniences to the harsh discomforts of Canada."19

18 The story of this exchange of letters with Chernivtsi was related to Navalkowsky by her grandfather, Nikon Shandro. According to another source, Metropolitan Volodymyr responded with the following words: "We are not able to send you a priest due to lack of funds but there is a Russian Orthodox Mission there which will assign a priest to you, and if necessary, you should join that Mission" (Tarasar, 69). Nikon Shandro (1869-1951) was born in Rus'kyi Banyliv, Vashkivtsi county, Bukovyna. He immigrated to Canada aboard the SS Brazilia, arriving in Halifax on 9 May 1899 with his wife Anna and three children. Three weeks later he filed for a homestead at SW 22-57-15 W4 in what became known as the Shandro district. Bishop Tikhon of the Russian Orthodox Mission consecrated the completed church, dedicated to the Dormition of the Virgin Mary, on 28 August 1904. Whereas one local history (Charuk, 104-5) identifies Stefan Gudzowaty as the master carpenter responsible for the construction of the sanctuary, a later publication (Willingdon History Book Committee, 109) only attributes the interior work to him, crediting Stefan Rosichuk as the trained and paid carpenter who oversaw the project.

19 See "A Message from the Orthodox Mission in Winnipeg, Canada" (Svet 25 February 1909), as translated and quoted by Panchuk, Bukowinian Settlements 70. The criticism was not unwarranted, for Orthodox priests in Bukovyna generally enjoyed a comfortable existence that they were understandably reluctant to exchange for the uncertainties and tough conditions of life in the frontier regions of the Canadian West. 
Besides the understandable difficulties in finding priests who would be willing to join the immigrants overseas, there were other explanations why the repeated appeals for assistance failed to move Orthodox authorities in Bukovyna. It has been suggested, for instance, that the fact that ethnic Romanian ecclesiastics dominated the leadership of the Bukovynian church was one of the reasons for the indifference shown toward the plight of the Ukrainian settlers in Canada. There is also evidence to suggest that the Metropolitanate of Chernivtsi feared upsetting Russian Orthodox Church officials in North America by throwing into question the latter's claims to jurisdictional exclusivity. Perhaps an even greater reason was that the conservative members of the Bukovynian consistory were fundamentally opposed to immigration, and even worked actively to discourage it. This is evident in a directive issued on 16 September 1911 instructing all parish priests to give sermons critical of emigration on the grounds that workers from Canada were "bringing back into our faith contrary, socialist, and pseudo-liberal teachings" (Botushans'kyi, “'My—brattia zamors'ki'” 104; see also his conclusions, 105).

Whatever the official or unofficial causes were as to why no clergy from Bukovyna ever followed their flock to Canada during the pioneer wave of Ukrainian immigration, the lack of support represented a distinct failure on the part of the mother church in Chernivtsi. At the very least, it was a missed opportunity for the Orthodox Church in Bukovyna to play a role in the spiritual development of the Ukrainian-Canadian community. One can only wonder how the religious organization of Ukrainians in Canada might have evolved had Orthodox priests or hieromonks been dispatched by the Metropolitanate of Chernivtsi to Bukovynian settlements in the formative years of Ukrainian institutional life in the New World. While it is unlikely that the Bukovynian church would have rivalled the dominance of the Russian Orthodox Mission in North America, the presence of Ukrainian clergy from Bukovyna could have forced accommodations from the Russian hierarchs in their dealings with the large number of Ukrainians who fell under their jurisdiction. The presence in Canada of Ukrainian clerics from Bukovyna might also have played a significant role in the 1918 founding of the Ukrainian Greek Orthodox Church of Canada, providing it with a readymade pool of priests to draw on and contributing to stabilizing and growing the formation in the first difficult years of its existence. 


\section{Works Cited}

Botushans'kyi, V. M. "Pochatky bukovyns'koi emihratsii v Kanadu." Mihratsiini rukhy $\mathrm{z}$ Zakhidnoi Ukrainy do Zakhidnoi Kanady: Materialy spil'nykh konferentsii / Migrations from Western Ukraine to Western Canada: Proceedings of the Joint Conferences. Eds. Oleksandr Makar and Radomir Bilash. Edmonton: Canadian Centre for Culture and Ethnography, University of Alberta, Historic Sites Service, Alberta Community Development, 2002. 77-80. Print.

---, '“My-brattia zamors'ki...' (Z istorii tserkovno-relihiinykh stosunkiv bukovyns'kykh emihrantiv pershoi khvyli u Kanadi z Bukovyns'koiu pravoslavnoiu konsystoriieiu." Humanitarna osvita: Faktor svitovoi intehratsii. Materialy mizhnarodnoi naukovo-praktychnoi konferentsii. Pt. 1. Chernivtsi: Ministerstvo osvity Ukrainy et al, 1997. 100-07. Print.

Botushans'kyi, V. M. and H. V. Chaika, Emihratsiia z Bukovyny (60-ti rr. XIX pochatok XX. st.). Chernivtsi: Tekhnodruk, 2009. Print.

Bozhyk [Bozyk], Fr. Panteleimon. Chomu ia navernuvsia.... Mundare: Basilian Fathers Press, 1945. Print.

---, Tserkov ukraintsiv v Kanadi. Winnipeg: Kanadyis'kyi Ukrainets', 1927. Print.

Charuk, Myrtle, ed., The History of Willingdon 1928-1978. St. Paul, AB: L. H. Drouin, St. Paul Journal, [1978]. Print.

"Church Consecration." Edmonton Bulletin 13 September 1901: 5. Print.

Demczuk, Rev. [B.] "St. Nicholas Ukrainian Orthodox Congregation, MacNutt, Saskatchewan." Shell River Municipality, Century One, 1881-1984: Memories of Roblin and District. Vol. 1. Roblin, MB: Roblin History Book Committee, 1986. Print.

Galician settlers. Letter to the Holy Synod in St. Petersburg. 5 June 1898. Alaska Russian Church Archives (ARCA), reel 321.

Kamnev, Fr. Dimitrii and Deacon Vladimir Aleksandrov. "Poezdka v Sev[ero]Zapadnuiu Kanadu," Amerikanskii pravoslavnyi vestnik 3.16 (15-27 August 1899): 441. Print.

Kamnev, Fr. Dmitrii. "Pravoslavie v Kanadi," Amerikanskii pravoslavnyi vestnik 2.1 (1-13 September 1897): 26-29. Print.

Kaye, Vladimir. Early Ukrainian Settlements in Canada, 1895-1900. Toronto: University of Toronto Press, for the Ukrainian Canadian Research Foundation, 1964. Print.

Korchyns'kyi, Fr. Yakiv. Letter to Bishop Tikhon. 23 March 1902. Alaska Russian Church Archives (ARCA), reel 361.

Namee, Matthew. "Fr. Jacob Korchinsky: Missionary and Martyr." OrthodoxHistory.org. The Society for Orthodox Christian History in the Americas. 6 Jan. 2010. Web. 10 Feb. 2014. <http://orthodoxhistory.org/ 2010/01/06/fr-jacob-korchinsky-missionary-and-martyr/>.

Navalkowsky, Anna. "Shandro Church." Alberta History 30.4 (Autumn 1982): 25-30. Print.

Nemyrs'kyi, Teodor. Letter to Bishop Tikhon. 19 February 1901. Alaska Russian Church Archives (ARCA), reel 321. 
Panchuk, John. Bukowinian Settlements in Southern Manitoba. Battle Creek, Ont.: n.p., 1971. Print.

Pravoslavnyi amerikanskii vestnik (New York) 1.11 (1-13 February 1897): 212-13. Print.

Protopopov, Michael Alex. "The Russian Orthodox Presence in Australia: The History of a Church Told from Recently Opened Archives and Previously Published Sources." Diss. Australian Catholic University, 2005. <http:// dlibrary.acu.edu.au/digitaltheses/public/adtacuvp87.09042006/02whole.pdf>.

St. Michael's Ukrainian Greek Orthodox Church. [Winnipeg]: Manitoba Department of Cultural Affairs and Historical Resources, Historic Resources Branch, 1981. Print.

Sych, O. I., ed. and comp. Z "Novoho kraiu”: Lysty ukrains'kykh emigrantiv z Kanady. Research Report no. 45. Edmonton: Canadian Institute of Ukrainian Studies, 1991. Print.

Tarasar, Constantine J. et al., eds., Orthodox America 1794-1976. Syosset, N.Y.: The Orthodox Church in America, Department of History and Archives, 1975. Print.

Willingdon History Book Committee, Early Foundations: Willingdon and Area History. Edmonton: Willingdon History Book Committee, 1990. Print. 